\title{
Active or Passive? Reforming Employment Benefits in the OECD
}

\author{
José Alemán ${ }^{1}$ \\ ${ }^{1}$ Political Science Department, Fordham University, Bronx NY, USA \\ Correspondence: José Alemán, Political Science Department, Fordham University, 441 East Fordham Road, \\ Bronx, NY 10458, USA. Tel: 1-718-817-3955. E-mail: aleman@fordham.edu
}

\author{
Received: September 8, 2012 Accepted: October 2, 2012 Online Published: October 29, 2012 \\ doi:10.5539/res.v4n5p94 \\ URL: http://dx.doi.org/10.5539/res.v4n5p94
}

\begin{abstract}
The last three decades witnessed attempts to reduce employment benefits in many OECD countries. This study distinguishes between three types of benefits: employment protection legislation (EPL), active labour market policies (ALMPs), and unemployment compensation. Using structural equation modeling, the study systematically examines the determinants of these benefits in 23 countries (1985 to 2008). The analysis contributes to the welfare state literature in at least three ways. First, it goes beyond studies of individual programs or overall "welfare effort" by examining three programs simultaneously. Second, it uncovers both direct and indirect channels of support for these programs. Finally, the analysis reveals, contrary to previous findings, that strict employment protection is quite compatible with more spending on ALMPs and unemployment compensation in some countries.
\end{abstract}

Keywords: unemployment benefits, compensation, EPL, ALMPs, globalization

\section{Introduction}

Advanced industrialized democracies witnessed high levels of unemployment and slow job growth in the last three decades (Mares, 2004, 2006). To address this situation, countries can increase funding for such programs as unemployment compensation (also known as replacement rates) and active labour market policies (ALMPs) (Note 1). Yet the current climate of globalization is said to pressure countries to reduce social benefits. In this climate, it is worth asking what programs can be more easily funded.

This study examines possible trade-offs among competing employment insurance programs. While numerous scholars have examined reforms to social benefits in the OECD (e.g., Huber \& Stephens, 2001), these studies either evaluate overall spending or track particular programs (cf. Swank \& Martin, 2001; Martin \& Swank, 2004), downplaying the possibility that the existence of one program may affect another serving a similar need and/or constituency. In contrast, this paper studies the determinants of three employment insurance programs simultaneously, reflecting the reality that politicians and interest groups must consider what resources to allocate to a menu of programs.

Building on the distinction between employment protection (EPL) and unemployment benefits (unemployment compensation and ALMPs), the paper demonstrates that EPL is quite compatible with generous funding for unemployment benefits in certain countries. The findings carry considerable import for at least three reasons. First, employment protection has declined in recent decades in many OECD countries, particularly in the more regulated ones (Organisation for Economic Co-operation and Development [OECD], 2006), raising the possibility that similar trends have affected funding for unemployment benefits. Secondly, a number of important works predict that levels of EPL would have to decline for spending on unemployment benefits to increase. If one were to find instead that the relaxation of employment protection has not affected spending on unemployment benefits, this would demonstrate resilience on part of the welfare state in advanced democracies. Finally, it is important to ascertain if ALMPs and unemployment compensation are being funded at similar levels. Unemployment compensation - a passive labour market policy, merely replaces income at a specified level and for a predetermined period (Huo, 2009), which could make it more difficult to fund than ALMPs (Note 2).

The findings also shed light on a debate between competing explanations of social policy in advanced democracies. Students of labour politics, for example, see labour market insiders as the main beneficiaries of high employment protection. Consequently, they regard EPL as an obstacle to more funding for unemployment benefits. What these scholars have not anticipated is that unions in certain countries support policies that favour 
both labour market insiders and outsiders. Followers of the varieties of capitalism (VoC) approach, on the other hand, do not regard employment protection as standing in the way of more spending on unemployment benefits. Scholars in this tradition, however, have not explicitly considered the indirect role labour market institutions play in sustaining social programs.

The paper proceeds as follows. In the first section, I highlight the challenges employment benefits face in developed democracies. In section two, I derive a series of propositions to explain changes to these benefits in the short-term as well as the sources of continuity for particular programs. The third section describes the data to be analyzed and the empirical strategy followed. The final section concludes with a discussion of the results.

\section{Continuity and Change in Unemployment Benefits}

EPL and unemployment benefits both insure workers against job losses, but there is a fundamental difference between these programs. Unemployment benefits insure workers throughout the economy, whereas EPL is consigned to the firm. Not surprisingly, scholars differ in their assessments of support for these programs.

When it comes to workers, labour scholars distinguish between those that have managed to obtain permanent status and benefits, or insiders, and those with temporary contracts and no benefits, or outsiders (Rueda, 2005) (Note 3). The risk of future unemployment is said to be lower for insiders, who want less unemployment compensation and ALMPs than outsiders. In addition, insiders oppose both the taxes needed to fund unemployment benefits, and the potential competition that would ensue if outsiders were able to upgrade their skills. Labour market insiders, instead, find it more expedient to protect themselves through employment protection legislation (or EPL) (Kim, 2007). If insiders constitute the majority in a country, political economists expect unions to privilege their interests (Kim, 2007; Rueda, 2006, 2007). Employers for their part should oppose EPL on grounds that it makes it more difficult for them to hire and fire workers. They should also oppose the taxes they have to pay in order to fund unemployment benefits (Rueda, 2007).

Scholars in the varieties of capitalism ( $\mathrm{VoC}$ ) approach, on the other hand, expect the skill composition of the economy, not the position of particular groups in the labour market, to drive preferences towards employment insurance (Mares, 2001, 2003; Swenson, 2002). Advanced industrialized democracies, the argument goes, are divided into two camps - liberal market economies (LMEs) and coordinated market economies (or CMEs) based on institutional synergies operating across nine spheres of society including firms, the state, interest groups, and workers (Amable \& Palombarini, 2009) (Note 4). If these scholars are correct, unions and employers, particularly in CMEs, have reasons to support EPL in good economic times. Employers consent to EPL, a form of market power for insiders, because firms incur labour turn-over costs (Lindbeck \& Snower, 2001). These costs are said to be higher in CMEs than in LMEs, since the former tend to rely more on specific as opposed to general skills.

In tough economic times, however, these regulations can impose a burden for firms since they involve a transfer of income to their protected employees when the firm would be better off laying-off these workers (OECD, 2004). As studies of employment performance have documented, countries with more protective dismissal regulations discourage firms from hiring when labour demand rises and firing when demand falls, increasing the unemployment rate (Bradley \& Stephens, 2007; Botero, Djankov, La Porta, Lopez-de-Silanes, \& Shleifer, 2004). By giving employers an incentive to shift wage and employment opportunities to outsiders, moreover, high levels of EPL also threaten the future wages and employment security of insiders (Lindbeck \& Snower, 2001). It is important to know then whether unions and employer associations favour reductions in EPL in exchange for more spending on unemployment benefits (Note 5).

\section{Preferences for Employment Insurance Reforms}

Students of labour politics base their predictions regarding support for unemployment benefits on insiders' opposition to any form of social policy. Only if EPL is reduced, the argument goes, would insiders support unemployment benefits, since more flexible employment regulations have the potential to turn them into outsiders (Rueda, 2008). From the VoC perspective, however, these arguments fail to consider the possibility that unions may respond to the needs of the entire labour force and not simply pursue policies that primarily benefit insiders (Bradley, Huber, Moller, Nielsen, \& Stephens, 2003). Consequently, it is important to ask if EPL does indeed have to decline for unions and employers to support more spending on unemployment benefits.

Reducing EPL creates more employment opportunities for outsiders and the unemployed, which reduces the tax wedge, since more employment leads to a larger pool of workers from which the payroll taxes needed to fund unemployment benefits are drawn (Bradley \& Stephens, 2007) (Note 6). But unemployment benefits require that politicians, interest groups, and program beneficiaries weigh the potential benefits of the policies in light of their 
short term costs. ALMPs in particular are not very effective in reducing unemployment rates or spells, but they seem to increase a country's stock of human capital, particularly after the first year (Note 7). This leads to the first hypothesis examined in this study:

H1: Reducing EPL in CMEs with high employment protection is not necessary to fund unemployment benefits. If fact, strict EPL should be associated with more spending for ALMPs and unemployment compensation if the two are complementary, as the $\mathrm{VoC}$ literature implies.

Globalization is said to force reforms on countries that are difficult to negotiate and implement. Consequently, it is important to ask how the political process and labour market institutions mediate the effects of globalization on employment insurance programs. A rich literature in comparative political economy sees corporatist councils, centralized and encompassing unions, and left governments as guarantors of generous social benefits (Esping-Andersen, 1985; Huber \& Stephens, 2001; Korpi, 2006) (Note 8).

Proponents of corporatism note that the latter resolves conflicts among the groups involved, resulting in benefits for them as well as society overall. Huo (2009) claims for example that corporatism blunts the insider-outsider divide, suggesting it has the potential to forge trade-offs that result in higher unemployment benefits. Others, however, question corporatism's presumed advantages. Rueda (2007, p. 68) claims, for example, that "corporatism seemed to insulate insiders from unemployment and to make their preferences more different from those of outsiders." In these circumstances, collective bargaining may not resolve differences among participants in favour of more generous employment benefits.

While corporatism may not lead directly to higher spending on unemployment benefits, some scholars suggest that it should do so indirectly. Swank and Martin (2001) find in this regard that the centralization and cohesion of employer groups increases business support for social policy in general and ALMPs in particular (Martin \& Swank, 2004). The strength of employer organizations appears sufficient to affect business support for social policy in CMEs. These countries feature national level bargaining among state, business and labour representatives. Unions are also quite cohesive and strong in CMEs. As a result, employer and union support for social policy may manifest itself through the institution of corporatism. These observations lead to the second hypothesis explored in this study.

H2: High levels of corporatism and union density should be associated with more spending on unemployment benefits both directly, and indirectly through their effects on EPL.

When it comes to the role of governments some have argued that left governments have adapted to the inevitability of retrenchment by discouraging employment protection (Huo, Nelson, \& Stephens, 2008) and other passive benefits while encouraging activation (Huo, 2009). Others are much less sanguine about the ability of left parties to disregard the electoral consequences of their policies (Rueda, 2007, 2008). In this view, insiders are the mainstay of social democracy. Consequently, left parties promote pro-insider policies like employment protection (Rueda 2005).

Some scholars have stressed the lack of partisan effects on policy changes (Huber \& Stephens, 2001). One factor weighing against government involvement in social policy is that policy makers may not believe their interventions are effective. Since social policy has to be coordinated with wage and other policies, governments never consider it in isolation. From this perspective, governments on the left may not exert more influence over social benefits than their right-wing or Christian democratic counterparts.

The preceding arguments suggest that simply evaluating the direction and magnitude of change in benefit generosity under different governments may not tell us enough about the relationship between politics and welfare state reforms. I thus entertain the possibility that employment benefit generosity is more a function of the type of government in power than its ideology. Multi-party systems with a degree of logrolling and coalition building, for example, tend to result in higher expenditures on social programs (Huber, Ragin, \& Stephens, 1993; Swank, 2002). These propositions lead to the third hypothesis explored in this study:

H3: The type of government, rather than its ideology, should be significantly related to unemployment benefit generosity. Nevertheless, not all programs should elicit the same level of support. ALMPs, given their "less demanding nature" (Vis, 2010), should elicit more funding, in particular from coalition governments.

\section{Data and Empirical Model}

To test the argument about the relationship between EPL and unemployment benefits, as well as to examine dependencies among the different programs, I rely on an balanced panel of OECD nations from 1985 - roughly the year in which European economies started to reform their employment protection statutes - to 2008 (Note 9). For both substantive and methodological reasons, I employ simultaneous equations, which have not been widely 
used in the literature on welfare spending in general and OECD countries in particular. A reading of the literature however, particularly works associated with the $\mathrm{VoC}$ approach, underscores the dependencies among employment benefit programs in particular countries. Unemployment compensation and ALMPs, for example, are very highly and significantly correlated $(r=0.59 ; \mathrm{p}<0.000)$.

Simultaneous equation models allow the analyst to specify systems of equations in which two or more dependent variables share one or more form(s) of dependency. That is, a variable may be both a dependent (or endogenous) variable in one equation and a predictor (or exogenous) variable in another equation. One or more dependent variable(s) may be explained by the same exogenous variable(s). Finally, the error terms of the equations may be correlated. More specifically, the models estimated form a partially recursive system of seemingly unrelated regressions with correlated errors of the form:

$E P L_{i t}=\beta_{\text {corporatism }}+\beta$ left government $t_{i t}+\beta$ government type $e_{i t}+$

Bunion density $_{i t}+\beta$ unemployment ${ }_{i t}+\beta$ deindustrialization $_{i t}+\beta_{\text {globalization }}+\varepsilon_{i t}$

$U C_{i t}=\beta E P L_{i t}+$ corporatism $_{i t}+\beta$ left government $_{i t}+\beta$ government type $_{i t}$

$+\beta_{\text {union density }}+$ Bunemployment $_{i t}+\beta$ deindustrialization $_{i t}+\beta$ deficit $_{i t}$

+ Bglobalization $_{i t}+$

$\beta$ vetos ${ }_{i t}+\varepsilon_{i t}$

$A L M P_{i t}=\beta E P L_{i t}+\beta$ corporatism $_{i t}+\beta$ left $_{\text {government }}$ it $^{+}$

$\beta_{\text {government type }}+$ Bunion density $_{i t}+$ Bunemployment $_{i t}+\beta$ deindustrialization $_{i t}+\beta$ deficit $_{i t}$ + Bglobalization $_{i t}+\beta_{\text {vetos }}+\varepsilon_{i t}$

where $U C_{i t}$ stands for unemployment compensation in country $i$ and year $t$ and the vector of errors, denoted by $\varepsilon$, is robust to any pattern of heteroskedasticity and serial correlation within countries (Note 10). I first estimate a pooled model that reveals the combined effect of levels of particular covariates as well as changes over time in those covariates, on the dependent variables. Although the data is a balanced panel, it contains missing observations, which would render the panel unbalanced after listwise deletion. This introduces significant heterogeneity into the estimation of the coefficients. Consequently, I estimate the model using maximum likelihood with missing values (Stata Press, 2011). By multiply imputing the missing data, this method produces more efficient estimates than listwise deletion so long as variables are jointly normal in their distribution (Note 11).

Although the results from this preliminary analysis indicate the model is capturing most of the variation in the data, it is possible that country-specific unobserved factors could be affecting the results. This heterogeneity is typically handled using fixed or random effects for countries. Fixed effects, because they are correlated with variables that are time-invariant, provide estimates of the effect of changes in the time-varying covariates on changes in the dependent variable. Random effects, while also allowing for unobserved heterogeneity at the country level, provide a matrix-weighted average of within and between effects. Random effects, however, models country-specific indicators as randomly distributed while assuming no correlation between these indicators and explanatory variables. I am interested in how changes in certain variables have affected employment benefits. In addition, the assumption of no correlation between country indicators and explanatory variables is problematic. Consequently, I present a second set of results based on within-country transformations of the variables that is equivalent to a seemingly unrelated regression with fixed effects (Note 12). While listwise deletion creates an unbalanced panel, the fixed effects ensure results are asymptotically efficient (Note 13), eliminating any threats to valid inference.

It is important to emphasize that the variables budget deficit and veto points were not included in the model predicting the strictness of EPL. The reason for this omission is that while the literature is clear on what effects these variables should have on the two measures of cash expenditure, there are no hypotheses linking them to the strictness of EPL. Additionally, since employment protection was widely adopted in the OECD in the early 1970s (Rueda, 2005) but has experienced declines in recent decades, EPL is also included on the right hand side of the models for ALMPs and unemployment benefits. The reader should note that structural equation modeling shares with other families of models with which it is closely related - such as instrumental variables estimation the property that it allows for effects that are both direct and indirect. Indirect effects could occur if an exogenous variable affects an endogenous variable which is then used to predict a different endogenous variable. In our case, corporatism and union density could have both direct and indirect effects on unemployment benefits, since the former are used to explain levels of EPL, which in turn predict spending on benefits alongside corporatism and union density.

Substantively then, one could think of the OECD as a conglomeration of countries with different welfare state profiles that are in large measure a function of differences in economic, social, and political institutions. In recent 
years, scholars have demonstrated powerful synergies between political institutions such as the electoral system and economic and social institutions such as the system of interest group representation (e.g., Birchfield \& Crepaz, 1998; Crepaz \& Moser, 2004; Iversen, 2005; Lijphart, 1999) (Note 14). If the economies of advanced industrialized democracies cluster in groups that are institutionally congruent (Hall \& Soskice, 2001), then model covariates may explain dependent variables through more than one path.

The first dependent variable in the analysis is then an indicator of employment protection derived from the OECD.Stat dataset (Note 15). While most of the sub-components used to calculate these scores refer to national and/or regional legislation, employment protection provided through collective bargaining has been incorporated where this is an important source of additional protection. The indicators also cover some important aspects of enforcing employment protection (Venn, 2009). As a result, scores reflect the approach taken in the empirical and theoretical literature, which regards employment protection as a cost employers must bear for adjusting employment levels (Botero et al., 2004; Heckman \& Pagés-Serra, 2000) (Note 16).

The remaining two dependent variables are measures of cash expenditure from public and mandatory private sources on unemployment compensation and ALMPs. Both are derived from the Comparative Political Data Set (Armingeon et al., 2011). One advantage of using these measures is that they represent an indicator of overall "societal effort" devoted to compensating or retraining the unemployed (Note 17). The measures are also weighted by GDP and, as such, can be directly compared (Note 18). The following section provides a brief description of the independent and control variables employed in the analysis:

Corporatism: The dominant level of collective bargaining is typically a good proxy of labour's ability to bargain with employers and the government on an equal footing. The measure used ranges from a value of 5 representing national or central level bargaining, to 1 representing local or company bargaining.

Information on the dominant level of bargaining comes from the Database on Institutional Characteristics of Trade Unions, Wage Setting, State Intervention and Social Pacts, 1960 and 2010 (Visser, 2011).

Cabinet composition: If left governments promote pro-insider policies such as employment protection, partisanship would affect unemployment benefits conditional on the strictness of employment regulation (Rueda, 2007). Empirically, this means including an interaction between this variable and EPL. Since governments could affect compensation and ALMPs both directly and through EPL and simultaneous equation modeling allows for both direct and indirect effects, I do not include interactions between this variable and EPL in the models for both forms of cash expenditure.

The indicator used is a measure of the centre of gravity of the cabinet on a left-right spectrum in a given country-year. Its five categories range from conservative hegemony (1), to social democratic and leftist hegemony (5).The measure is also derived from the Comparative Political Data Set.

Union density: I use a measure of net union membership defined as the proportion of employed minus retired and unemployed union members. The source for this measure is also the ICTWSS database.

Unemployment rate: Countries with higher rates of unemployment tend to have more generous unemployment benefits (Bassanini \& Duval, 2006; Blanchard \& Wolfers, 2000), since these entitlements respond somewhat automatically to perceived need (Huber \& Stephens, 2001). High levels of unemployment also make insiders more vulnerable and hence more like outsiders (Vis, 2011), increasing their support for these benefits. As a result, the analysis would be incomplete without controlling for the level of unemployment.

The unemployment rate is measured as the proportion of the labour force without a job (adjusted for seasonal variations) and is derived from the Comparative Political Data Set.

De-industrialization: much emphasis has been placed on the decline in manufacturing and the shift to services in many OECD economies. Since the 1960s, deindustrialization has increased pressures on policy makers to assist those in transition from traditional industrial jobs (Iversen \& Cusack, 2000; Iversen, 2001). Thus, at the national level, one should expect spending on unemployment compensation and ALMPs to increase with increases in de-industrialization.

I follow Iversen and Cusack (2000) and measure de-industrialization as 100 minus the sum of industrial and agricultural employment as a percentage of the working-age population. All component indicators of this variable were derived from the OECD.Stat dataset.

Economic globalization: Political economists have long noted that rising trade and investment flows affect social spending (Cameron, 1978; Garrett, 1998; Katzenstein, 1985; Rodrik, 1998). While some see economic openness as creating economic volatility that is translated into political support for more universal welfare programs (Boix, 
2003; Mares, 2005), others argue that if employers are allowed to invest elsewhere, they can use the threat of exit to demand tax and social policy concessions from governments and organized labour (Bradley et al., 2003). It is also possible of course that a shift to services and away from manufacturing has served as catalyst for rising trade and financial flows. My expectations regarding this variable are consequently mixed.

I use a measure of economic globalization developed by Axel Dreher (2006) that combines actual financial and trade flows with legal barriers to these flows.

Budget deficit: The ability of governments to fund unemployment benefits depends critically on the health of public finances. Budget deficits make it difficult for cabinets to allocate funding, particularly if spending is more discretionary as it is expected to be in the case of ALMPs.

Following the use of this variable in previous studies (e.g., Rueda, 2007), I derive a measure of the annual deficit as a percentage of GDP from the Comparative Political Data Set.

Veto points: Both the number and the ideological distance among veto players matter for social policy (Ha, 2008; Tsebelis, 2002). As scholars have pointed out, both factors are inversely related to the capacity of a political system to implement new fiscal policies (Birchfield and Crepaz, 1998; Crepaz, 1998, 2002; Crepaz and Moser, 2004). In the era of globalization, however, it is possible that dispersion of power through constitutional structures can work "in favour of more generous welfare states, by slowing down retrenchment" (Huber \& Stephens, 2001, p. 32).

I rely on an additive index of constitutional veto players from the Comparative Political Data Set that takes into account five indicators: the existence of a unitary as opposed to a federal state, a parliamentary versus presidential government, a proportional representation versus a single member majoritarian electoral system, a unicameral versus a bicameral legislature, and the existence of frequent referenda (Note 19). By construction, higher numbers imply more numerous and/or more competitive veto points (Note 20).

As Iversen (2005) and Iversen and Soskice (2006) have argued, however, countries with proportional representation electoral systems are more likely to develop multiparty political systems with centre-left cabinets, whereas countries with first past the post electoral systems tend to develop two dominant political parties with centre-right governments. The electoral system in place in a particular country is thus responsible not only for a certain number of veto players - the number of parties in the government, but also for their ideology. The nature of the electoral system - more proportional versus less - is also highly and significantly correlated with the dominant level of wage bargaining $(r=0.52 ; \mathrm{p}<0.000)$. As a result, I drop the electoral system component from the additive index.

As an indicator of the ideological distance among different government parties, the analysis already controls for the partisan "centre of gravity" in the cabinet. Obviously, the less polarized the ideological spectrum, the more spending on a particular benefit should increase. But the cabinet composition measure does not say anything about the number of parties in the cabinet or their relationship with the legislature. As a result, I also include a measure of government type derived from the Comparative Political Data Set.

Government type. This is categorical variable ranging from 1 to 6 , where 1 indicates single party cabinets with a parliamentary majority, 5 indicates minority governments with multiple political parties in the cabinet and no majority in parliament, and 6 is used to represent caretaker governments. By construction, this variable is exogenous to the additive index of constitutional structures, even in the case of presidential democracies with first past the post electoral systems, which tend to feature single party majority cabinets. As Lijphart (1999) argues, the electoral system is ultimately what determines whether the cabinet is formed only by one party or a coalition, although the kind of parliamentary support a cabinet enjoys is also important to the definition of different cabinets.

In presidential systems, the cabinet is not an extension of parliament, as in parliamentary systems. As a result, it adds to the number of veto players with the capacity to hinder policy change unless "the same party or coalition of parties controls all of the decision making organizations" (Ha, 2008, p. 793) (Note 21). Since the presidential or parliamentary character of the political system is included separately, our measure of cabinet composition helps to distinguish between countries where partisan veto players may be more numerous but also more cooperative (CMEs with minority coalition governments) and countries where veto players may be less numerous but more competitive (LMEs with single party governments) (Birchfield \& Crepaz, 1998; Crepaz, 1998, 2002; Crepaz \& Moser, 2004). Governments become less majoritarian as values on this variable increase. I thus use the first category as the reference in the empirical analysis, with indicator variables for each subsequent category summarizing their effect in relation to single party governments with a parliamentary majority (Note 22). 


\section{Results and Discussion}

Table 1 presents three sets of results for the three employment benefit programs discussed above. For any given independent variable, direct effects are reported first, followed by indirect and total effects. Since EPL is both an endogenous and an exogenous variable in the model, indirect effects refer to the effect of a particular covariate on compensation and ALMPs through their effect on EPL. Total effects are simply given by the sum of direct and indirect effects. To facilitate comparison of the magnitude of the coefficients, all independent variables have been standardized. Coefficients can then be interpreted as the number of standard deviations a dependent variable will change, per standard deviation increase (decrease) in the predictor variables.

.Table 1. Pooled structural equation model of employment benefits, 1985-2008

\begin{tabular}{|c|c|c|c|}
\hline Independent variables & EPL & $\mathrm{UC}$ & ALMPs \\
\hline \multicolumn{4}{|l|}{ Direct effects } \\
\hline EPL & & $0.202 *$ & $0.367 * *$ \\
\hline corporatism & $0.438 * * *$ & -0.112 & -0.096 \\
\hline cabinet composition & $0.163^{*}$ & -0.039 & -0.019 \\
\hline minimal winning coalition government & $0.237 *$ & 0.109 & 0.034 \\
\hline surplus coalition government & 0.130 & 0.056 & 0.101 \\
\hline single party minority government & $0.210^{*}$ & 0.034 & 0.156 \\
\hline multiparty minority government & 0.119 & 0.172 & $0.171 * *$ \\
\hline union density & -0.181 & $0.350^{* *}$ & $0.425 * * *$ \\
\hline unemployment & 0.216 & $0.475^{* * *}$ & 0.067 \\
\hline deindustrialization & -0.335 & $0.252 *$ & $0.441 * *$ \\
\hline globalization & -0.251 & $0.250 * *$ & $0.332 * *$ \\
\hline budget deficit & & $-0.149 * *$ & $-0.146 * *$ \\
\hline veto players & & $0.171 * *$ & 0.137 \\
\hline \multicolumn{4}{|l|}{ Indirect effects } \\
\hline corporatism & & $0.088^{* *}$ & $0.161 * *$ \\
\hline cabinet composition & & 0.033 & $0.060^{*}$ \\
\hline minimal winning coalition government & & 0.048 & $0.087 *$ \\
\hline surplus coalition government & & 0.026 & 0.048 \\
\hline single party minority government & & 0.042 & 0.077 \\
\hline multiparty minority government & & 0.024 & 0.044 \\
\hline union density & & -0.036 & -0.066 \\
\hline unemployment & & 0.044 & 0.079 \\
\hline deindustrialization & & -0.067 & -0.123 \\
\hline globalization & & -0.051 & -0.092 \\
\hline \multicolumn{4}{|l|}{ Total effects } \\
\hline EPL & & $0.202 *$ & $0.367 * *$ \\
\hline corporatism & $0.438 * * *$ & -0.024 & 0.065 \\
\hline cabinet composition & $0.163 *$ & -0.006 & 0.041 \\
\hline minimal winning coalition government & $0.237 *$ & $0.157 *$ & 0.121 \\
\hline surplus coalition government & 0.130 & 0.082 & $0.148^{*}$ \\
\hline single party minority government & $0.210^{*}$ & 0.076 & $0.233 *$ \\
\hline multiparty minority government & 0.119 & 0.196 & $0.215 * *$ \\
\hline union density & -0.181 & $0.314 * *$ & $0.359 * *$ \\
\hline unemployment & 0.216 & $0.518 * * *$ & 0.147 \\
\hline deindustrialization & -0.335 & 0.184 & 0.319 \\
\hline globalization & -0.251 & $0.199 *$ & 0.240 \\
\hline budget deficit & & $-0.149 * *$ & $-0.146 * *$ \\
\hline veto players & & $0.171 * *$ & 0.137 \\
\hline$R^{2}+100$ & $0 . .534$ & $0 . .678$ & $0 . .592$ \\
\hline Overall $R^{2}$ & & $0 . .897$ & \\
\hline$N$ & & 1170 & \\
\hline
\end{tabular}

Note: ${ }^{*} p<0.1 ; * * p<0.05 ; * * * p<0.01$. Standardized coefficients reported. Countries included in the analysis are.

Australia, Austria, Belgium, Canada, Denmark, Finland, France, Germany, Greece, Iceland, Ireland, Italy, Japan, Luxembourg, Netherlands, New Zealand, Norway, Portugal, Spain, Sweden, Switzerland, the United Kingdom, and the United States. Germany refers to the Federal Republic of Germany (or West Germany) before 1991. 
Table 1 reveals that the models reported explain a great deal of variation, both overall and for the three individual employment benefit programs. The overall coefficient of codetermination, or $\mathrm{R}^{2}$, is 0.897 , whereas each of the estimated equations has an $\mathrm{R}^{2}$ higher than 0.5 . These are high values considering that the models do not include fixed effects for countries or years.

With respect to H1, the analysis confirms the expectation that higher levels of employment protection are significantly associated with more spending on ALMPs and unemployment compensation. The coefficient for EPL in both models, moreover, emerges as the second and third largest, respectively, in the table of total effects. This implies that as EPL increases by one standard deviation (or approximately 1 point), spending of compensation should increase by 0.20 percent of GDP. Given that the overall trend in recent decades has been for employment protection to decline, particularly in CMEs, this result contradicts previous work claiming that EPL would have to decline in order for spending on ALMPs to increase (Rueda, 2006, 2007). Rueda assumes, however, that "upscale groups" are universally opposed to unemployment benefits, whereas employers in CMEs should be supportive of unemployment benefits, for reasons that have already been discussed. Could employers favour cash benefits in countries with strict EPL while unions oppose it, in line with the expectation that insiders should oppose all spending on social policy?

The positive and statistically significant coefficient for union density in our models of ALMPs belies this expectation, as does the size of this coefficient, the second largest in the column for total effects. The coefficient for union density is also the second largest in the unemployment compensation model (after the coefficient on unemployment), although it is clear that unions give relatively more importance to ALMPs than income replacement.

Another way to verify the finding regarding the relationship between EPL and ALMPs is to multiply EPL scores by -1 , yielding a variable that reflects the tendency in recent decades to deregulate employment protection. Higher numbers then imply more employment flexibility and lower numbers stricter employment regulations. If such a transformation is carried out, the coefficients for EPL are exactly the same, but with their signs reversed. The results (not reported) indicate that employment flexibility is significantly associated with lower spending on ALMPs and compensation.

Turning now to $\mathrm{H} 2$, the results also confirm the insight that higher levels of collective bargaining are necessary to increase levels of EPL. As the table of total effects indicates, the coefficient on corporatism is both the largest and most significant in that equation. To put this finding in perspective, for each additional increase of one standard deviation in the level of collective bargaining (or 1.2 points), EPL should increase by almost half a standard deviation, or approximately half a point. The effect of corporatism on ALMPs and compensation is also indirect, as indicated by the size and significance of its coefficients in the table of indirect effects. This indicates that corporatism increases spending on unemployment benefits, controlling for the reality that some countries tend to fund more of both (the bivariate correlation between both types of benefits is 0.34 and highly significant statistically).

Assessing $\mathrm{H} 3$ involves discussing the effects of different types of governments. Confirming insider-outsider accounts of the role of partisanship in social policy, more left leaning cabinets are directly responsible for higher levels of EPL. Left cabinet composition is also indirectly related to higher levels of spending on ALMPs, although the significance of this variable for ALMPs disappears once total effects are considered. Confirming H3, coefficients for government type indicate that coalition governments tend to be significantly associated with employment benefits when compared to single party majority governments, in particular with spending on ALMPs. The findings are in line with recent research on partisanship and social policy in advanced democracies.

The findings with respect to corporatism provide support for arguments that it mostly benefits insiders. Corporatism in this analysis mainly affects the regulation of employment. The latter is a form of redistribution of income from employers and outsiders towards insiders. This effect is very large, the second largest indeed for models of total effects, but in line with $\mathrm{H} 2$, corporatism also indirectly affects spending on ALMPs and compensation.

The results largely confirm other important associations. Increases in unemployment are a very significant and large predictor of increases in compensation as a share of GDP. Each additional increase in the unemployment rate of one standard deviation, or approximately 3.5 percent, is expected to result in approximately half a percent of GDP devoted towards compensating the unemployed. Unemployment is indeed the variable with the largest coefficient in the model for UC. Increases in deindustrialization are directly associated with more spending on ALMPs (Martin \& Swank, 2004), although the significance of this result disappears once indirect effects have been taken into account. Finally, globalization exerts a positive and statistically significant effect on UC. 
Surprisingly, the higher the number of constitutional veto points, the more funding for unemployment compensation tends to increase. This same variable, however, is insignificantly related to spending on ALMPs. Although the result appears to contradict veto player theory, unemployment replacement in some federations is administered by provincial governments (or state governments in the United States). As a result, this type of spending may function as an automatic stabilizer that rises during economic downturns and falls when countries experience rebounds. In the era of globalization, the dispersion of power through constitutional structures acts to maintain funding for at least some social programs. A lowess (or locally weighted polynomial regression) plot of unemployment compensation as function of veto players (not shown) indicates, moreover, that the effect of constitutional structures on compensatory spending is curvilinear, that is, compensation increases it at first with additional veto points, declining after the variable reaches a score of 3 (Note 23).

The veto players variable is also highly invariant over time, resulting in a finding that could be mostly cross-sectional rather than time-series (Note 24). Without a more dynamic analysis, it will be difficult to know with certainty what is driving this finding. As a result, I carry out a within-country transformation of the variables in my dataset. This discards all cross sectional variation in favour of estimates of changes in covariates on changes in the dependent variables. As before, direct, indirect and total effects are provided, and standardized coefficients reported.

Table 2. Pooled structural equation model of change in employment benefits, 1985-2008

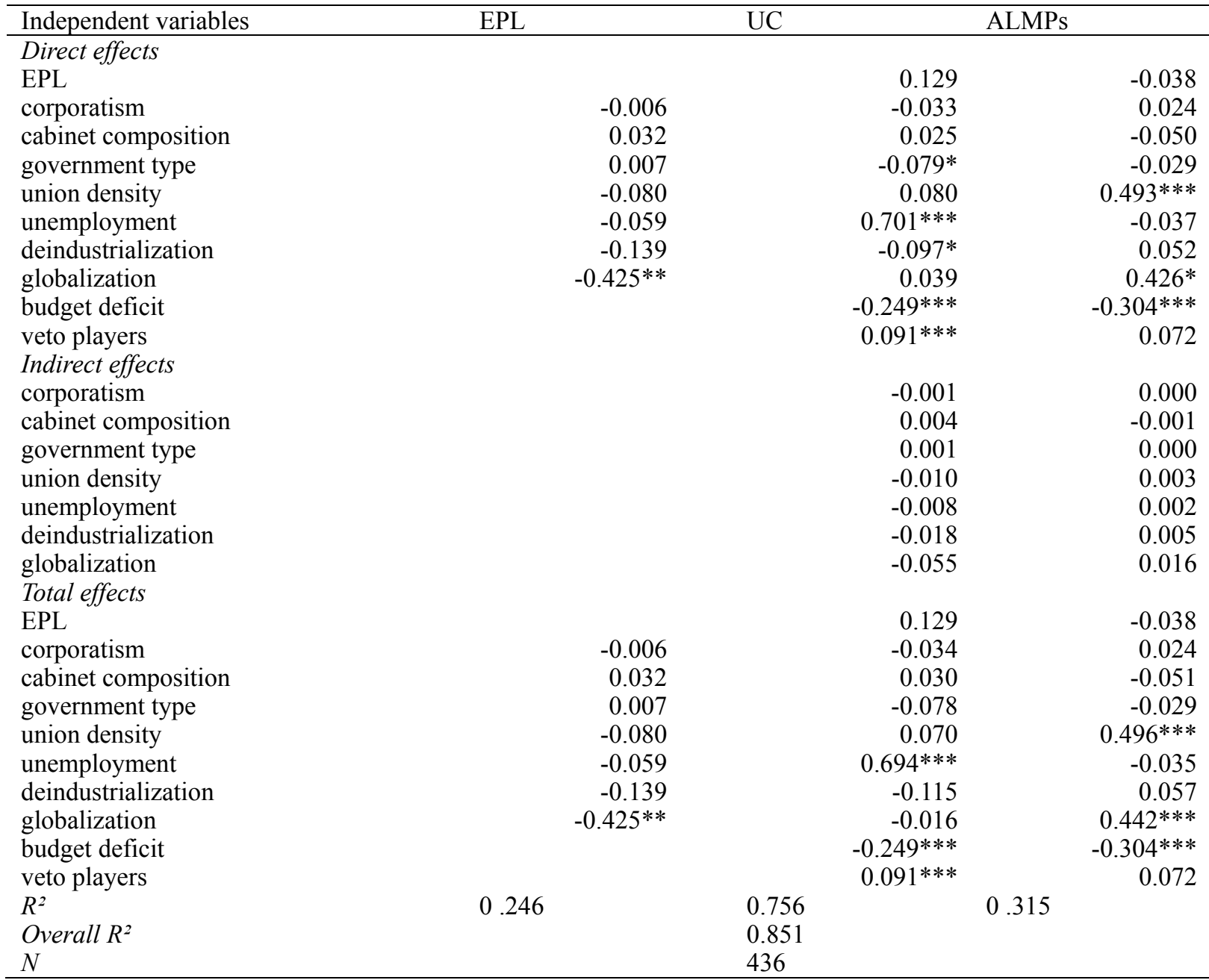

Note: $* p<0.1 ; * * p<0.05 ; * * * p<0.01$. Standardized coefficients reported. Countries included in the analysis are Australia, Austria, Belgium, Canada, Denmark, Finland, France, Germany, Greece, Ireland, Italy, Japan, Netherlands, New Zealand, Norway, Portugal, Spain, Sweden, Switzerland, the United Kingdom, and the United States. Germany refers to the Federal Republic of Germany (or West Germany) before 1991. 
Table 2 presents the second set of results based on within-country transformations of the variables. This time the variable government type has not been decomposed into its individual categories since there aren't enough degrees of freedom to perform the analysis. The variable is coded from increasing to decreasing majoritarianism, however, allowing for an intuitive interpretation of the results. Although not as many coefficients emerge significant statistically, the results clarify some of the findings reported in Table 1, with coefficients for certain variables retaining their sign and level of significance. The only major difference is that the variable globalization, which did not significantly explain levels and changes in EPL and ALMPs, has now become significant, indicating that as countries become more open to trade, foreign direct investment, and other financial flows, firms find it more profitable, and unions more viable, to trade laws that make hiring and firing more difficult for more spending on skill upgrading. The sign and significance of the veto players variable remains, although the coefficient is smaller in size. Together with the results reported in Table 1, the findings indicate that levels of unemployment compensation are greater in countries with more veto players and that increases in the number of constitutional veto players also result in more compensation.

From the variables with the largest coefficients reported in Table 2, it is clear that the changes that mattered the most in the last three decades are increases in unionization in some countries, which have resulted in more ALMP spending; increases in unemployed populations, which have resulted in increases in unemployment compensation; increases in globalization, which have led to more activation while simultaneously reducing employment protection; and increases in budget deficits, which have reduced the amount of funds available for both compensation and activation. Since globalization did not have a significant effect on levels of spending on ALMPs, we can now state that Martin and Swank's claim about the expansionary effects of deindustrialization reflects changes in globalization driving increases in activation. The findings reconcile the views of those who see globalization as a force pushing for a larger public sector (Boix, 2003; Cameron, 1978; Katzenstein, 1985; Mares, 2005; Rodrik, 1998) and those who expect it to create pressures to retrench social programs, in particular employment protection.

Cabinet composition is again not a significant determinant of changes in any of the programs. The findings confirm Huber and Stephen's (2001) claim that partisan effects have not featured very prominently on policy changes in the era of globalization. Government type is also not a significant explanator of changes in social policy, except in explaining changes in unemployment benefits in the table for direct effects. This result is marginally significant and washes out once total effects are considered. It is likely that its significance in Table 1 but lack of significance in Table 2 is due to it varying more between countries than within.

\section{Conclusion}

This study has provided a systematic analysis of the generosity of employment benefits in 23 OECD countries from 1985 to 2008. The analysis has relied on a methodology - structural equation modeling - that allows us to examine how different economic, political and institutional variables act to expand or reduce spending on these benefits, even in the presence of dependencies among the different programs. The literature on the welfare state in general and employment benefits in particular is somewhat partial. A more systematic approach is necessary to reveal which factors affect these programs and why both over time as well as between countries.

While no single factor explains why countries expand or reduce their employment benefits, the study found that strict levels of EPL can go hand in hand with funding for unemployment benefits. Another noteworthy finding is that corporatism affects cash expenditures through employment protection. Unions, one of the three pillars of corporatism, also play a determinative role in sustaining cash expenditure programs. Thirdly, the study found the type of government matters more to social policy than its partisanship, and not always in the way it had been previously stipulated.

Although substantial continuities in patterns of benefit generosity across political economies remain, the analysis points to ways in which small and incremental reforms can someday amount to profound changes in the OECD. There will always be losers from economic change such as the unemployed that clamour for compensation. In the current climate of globalization, they become more difficult to accommodate. But politicians should avoid the temptation to cut benefits too drastically. Instead, they should rely more on the logic of activation, which provides an investment in the labour force and society of the future. That some governments are able to implement these policies is cause for optimism, although the results presented in this paper suggest the policies are more likely to materialize in countries such as CMEs that feature certain clusters of institutions. In that sense, the analysis favours the VoC approach over studies that predict support for social policy based on the position of particular groups in the labour market. 


\section{Acknowledgements}

I would like to thank presenters at the Midwest Political Science Association annual conference in 2010, Bob Hume and Richard Fleisher from the Political Science Department at Fordham University, and an anonymous reviewer for helpful comments on various versions of this manuscript. I also want to acknowledge Kristin MacDonald from Stata Corporation for patiently answering my queries, and the Review editor for inviting and so promptly handling my submission.

\section{References}

Amable, B., \& Palombarini, S. (2009). A neorealist approach to institutional change and the diversity of capitalism. Socio-Economic Review, 7(1), 123-143. http://dx.doi.org/10.1093/ser/mwn018

Anderson, C. J. (2009). The private consequences of public policies: Active labor market policies and social ties in Europe. European Political Science Review, 1(3), 341-373. http://dx.doi.org/10.1017/S1755773909990130

Armingeon, K., Weisstanner, D., Engler, S., Potolidis, P., Gerber, M., \& Leimgruber, P. (2011). Comparative Political data set 1960-2009. University of Berne: Institute of Political Science. Retrieved from http://www.ipw.unibe.ch/content/team/klaus_armingeon/comparative_political_data_sets/index_ger.html

Bassanini, A., \& Duval, R. (2006). Employment patterns in OECD countries: Reassessing the role of policies and institutions. Paris: OECD Publishing.

Birchfield, V. L., \& Crepaz, M. M. L. (1998). The impact of constitutional structures and collective and competitive veto points on income inequality in industrialized democracies. European Journal of Political Research, 34(2), 175-200. http://dx.doi.org/10.1111/1475-6765.00404

Blanchard, O., \& Wolfers, J. (2000). The role of shocks and institutions in the rise of European unemployment: The aggregate evidence. Economic Journal, 110(462), 1-33. http://dx.doi.org/10.1111/1468-0297.00518

Boix, C. (2003). Democracy and redistribution. New York, NY: Cambridge University Press.

Botero, J., Djankov, S., La Porta, R., Lopez-de-Silanes, F., \& Shleifer, A. (2004). The regulation of labor. Quarterly Journal of Economics, 119(4), 1339-1382. http://dx.doi.org/10.1162/0033553042476215

Bradley, D., Huber, E., Moller, S., Nielsen, F., \& Stephens, J. (2003). Distribution and redistribution in postindustrial democracies. World Politics, 55(4), 193-228. http://dx.doi.org/10.1353/wp.2003.0009.

Bradley, D. H., \& Stephens, J. D. (2007). Employment performance in OECD countries: A test of neoliberal and institutionalist hypotheses. Comparative Political Studies, 40(12), 1486-1510. http://dx.doi.org/10.1177/0010414006292609

Cameron, D. R. (1978). The expansion of the public economy: A comparative analysis. American Political Science Review, 72(4), 1243-1261. http://dx.doi.org/10.1017/S0003055406302560

Card, D., Kluve, J., \& Weber, A. (2010). Active labor market policy evaluations: A meta-Analysis. NBER Working Paper No. 16173. Retrieved from http://www.nber.org/papers/w16173

Crepaz, M. M. L. (1998). Inclusion versus exclusion: Political institutions and welfare expenditures. Comparative Politics, 31(1), 61-80. http://dx.doi.org/10.2307/422106

Crepaz, M. M. L. (2002). Global, constitutional, and partisan determinants of redistribution in 15 OECD Countries. Comparative Politics, 34(2), 169-188. http://dx.doi.org/10.2307/4146936

Crepaz, M. M. L., \& Moser, A. W. (2004). The impact of collective and competitive veto points on public expenditures in the global age. Comparative Political Studies, 37(3), 259-285. http://dx.doi.org/10.1177/0010414003262067

Dreher, A. (2006). Does globalization affect growth? Evidence from a new index of globalization. Applied Economics, 38(10), 1091-1110. http://dx.doi.org/10.1080/00036840500392078

Esping-Andersen, G. (1985). Politics against markets: The social democratic road to power. Princeton: Princeton University Press.

Ha, E. (2008). Globalization, veto Players, and welfare spending. Comparative Political Studies, 41(6), 783-813. http://dx.doi.org/10.1177/0010414006298938

Hall, P. A., \& Soskice, D. (2001). Varieties of capitalism: The institutional foundations of comparative advantage. New York: Oxford University Press. 
Heckman, J., \& Pagés-Serra, C. (2000). The cost of job security regulation: Evidence from Latin American labor markets. Economia, 1(1), 109-154.

Huber, E., \& Stephens, J. D. (2001). Development and crisis of the welfare state: Parties and policies in global markets. Chicago: University of Chicago Press.

Huber, E., Ragin, C., \& Stephens, J. D. (1993). Social democracy, Christian democracy, constitutional structure, and the welfare state. American Journal of Sociology, 99(3), 711-749. http://dx.doi.org/10.1086/230321

Huo, J. (2009). Third way reforms: Social democracy after the golden age. New York: Cambridge University Press.

Huo, J., Nelson, M., \& Stephens, J. D. (2008). Decommodification and activation in social democratic policy: Resolving the paradox. Journal of European Social Policy, 18(5), 5-20.

Iversen, T. (2001). The dynamics of welfare state expansion: Trade openness, de-industrialization, and partisan politics. In P. Pierson (Ed.), The new politics of the welfare state (pp. 45-79). Oxford University Press: New York.

Iversen, T. (2005). Capitalism, democracy and welfare. Cambridge: Cambridge University Press.

Iversen, T., \& Soskice, D. (2006). Electoral institutions and the politics of coalitions: Why some democracies redistribute more than others. American Political Science Review, 100(2), 165-181. http://dx.doi.org/10.1017/S0003055406062083

Iversen, T., \& Cusack, T. R. (2000). The causes of welfare state expansion: Deindustrialization or globalization? World Politics, 52(3), 313-349. http://dx.doi.org/10.1017/S0043887100016567

Katzenstein, P. J. (1985). Small states in world markets: Industrial policy in Europe. Ithaca, N.Y.: Cornell University Press.

Kim, W. (2007). Social risk and social insurance: Political demand for unemployment insurance. Rationality and Society, 19(2), 229-254. http://dx.doi.org/10.1177/1043463107077388

Korpi, W. (2006). Power resources and employer-centered approaches in explanations of welfare states and varieties of capitalism: Protagonists, consenters, and antagonists. World Politics, 58(2), 167-206. http://dx.doi.org/10.1353/wp.2006.0026

Lijphart, A. (1999). Patterns of democracy: Government forms and performance in thirty-six countries. New Haven: Yale University Press.

Lindbeck, A., \& Snower, D. J. (2001). Insiders versus outsiders. The Journal of Economic Perspectives, 15(1), 165-188. http://dx.doi.org/10.1257/jep.15.1.165

Mares, I. (2001). Firms and the welfare state: When, why, and how does social policy matter to employers? In P. A. Hall, \& D. Soskice (Eds.), Varieties of capitalism: The institutional foundations of comparative advantage (pp. 184-212). Oxford: Oxford University Press.

Mares, I. (2003). The sources of business interest in social insurance: Sectoral versus national differences. World Politics, 55(2), 229-258. http://dx.doi.org/10.1353/wp.2003.0012

Mares, I. (2004). Wage bargaining in the presence of social services and transfers. World Politics, 57(1), 99-142. http://dx.doi.org/10.1353/wp.2005.0011

Mares, I. (2005). Social protection around the world: External insecurity, state capacity, and domestic political cleavages. Comparative Political Studies, 38(6), 623-651. http://dx.doi.org/10.1177/0010414004274403

Mares, I. (2006). Taxation, wage bargaining, and unemployment. Cambridge: Cambridge University Press.

Martin, C. J., \& Swank, D. (2004). Does the organization of capital matter? Employers and active labor market policies at the national and firm levels. American Political Science Review, 98(4), 593-611. http://dx.doi.org/10.1017/S0003055404041371

Organisation for Economic Co-operation and Development. (2004). OECD employment outlook 2004: Reassessing the OECD jobs strategy. Paris: Organisation for Economic Co-operation and Development.

Organisation for Economic Co-operation and Development. (2006). OECD employment outlook 2006. Paris: Organisation for Economic Co-operation and Development.

Organisation for Economic Co-operation and Development. (2009). OECD employment outlook 2009. Paris: Organisation for Economic Co-operation and Development. 
Rhodes, M. (2001). The political economy of social pacts: Competitive corporatism and European welfare reform. In P. Pierson (Ed.), The new politics of the welfare state (pp. 165-194). Oxford: Oxford University Press.

Rodrik, D. (1998). Why do more open economies have bigger governments? The Journal of Political Economy, 106(5), 997-1032. http://dx.doi.org/10.1086/250038

Rueda, D. (2005). Insider-outsider politics in industrialized democracies: The challenge to social democratic parties. American Political Science Review, 99(1), 61-74. http://dx.doi.org/10.1017/S000305540505149X.

Rueda, D. (2006). Social democracy and active labour market policies: Insiders, outsiders, and the politics of employment promotion. British Journal of Political Science, 36(3), 385-406. http://dx.doi.org/10.1017/S0007123406000214

Rueda, D. (2007). Social democracy inside out: Partisanship and labor market policy in industrialized democracies. Oxford: Oxford University Press.

Rueda, D. (2008). Left government, policy, and corporatism: Explaining the influence of partisanship on inequality. World Politics, 60(3), 349-389. http://dx.doi.org/10.1017/S0043887100009035

Scruggs, L. (2006). The generosity of social insurance, 1971-2002. Oxford Review of Economic Policy, 22(3), 349-364. http://dx.doi.org/10.1093/oxrep/grj021

Stata Press. (2011). Structural equation modeling reference manual. College Station: Stata Press.

Swank, D. (2002). Global capital, political institutions, and policy change in developed welfare states. New York: Cambridge University Press.

Swank, D. H., \& Martin, C. J. (2001). Employers and the welfare state: The political economic organization of firms and social policy in contemporary capitalist democracies. Comparative Political Studies, 34(8), 889-923. http://dx.doi.org/10.1177/0010414001034008003

Swenson, P. (2002). Capitalists against markets: The making of labor markets and welfare states in the United States and Sweden. Oxford: Oxford University Press.

Tsebelis, G. (2002). Veto players: How political institutions work. Princeton: Princeton University Press.

Venn, D. (2009). Legislation, collective bargaining and enforcement: Updating the OECD employment protection indicators. Retrieved from www.oecd.org/els/workingpapers

Vis, B. (2010). Politics of risk-taking: Welfare state reform in advanced democracies. Amsterdam: Amsterdam University Press.

Vis, B. (2011). Under which conditions does spending on active labor market policies increase? An fsQCA analysis of 53 governments between 1985 and 2003. European Political Science Review, 3(2), 229-252. http://dx.doi.org/10.1017/S1755773910000378

Visser, J. (2011). ICTWSS: Database on institutional characteristics of trade unions, wage setting, state intervention and social pacts in 34 countries between 1960 and 2007 (Version 3.0). University of Amsterdam: Amsterdam Institute for Advanced Labour Studies (AIAS). Retrieved from http://www.uva-aias.net/208

\section{Notes}

Note 1. ALMPs include "all social expenditure (other than education) which is aimed at the

improvement of the beneficiaries' prospect of finding gainful employment or to otherwise increase their earnings capacity. This category includes spending on public employment services and administration, labour market training, special programmes for youth when in transition from school to work, labour market programmes to provide or promote employment for unemployed ... and special programmes for the disabled." See OECD.Stat at http://stats.oecd.org/glossary/detail.asp?ID=28.

Note 2. Some have argued for example that by providing workers with job-related training, ALMPs change the skill composition of the labour force and in so doing, evoke gains for all involved. See Anderson (2009).

Note 3. Early retirees, the long-term unemployed, or those unable to enter the labour market are sometimes also considered outsiders. See Mares (2004).

Note 4. LMEs are countries where relations between firms and suppliers, investors, and other firms are coordinated primarily by competitive markets. LMEs refer to Australia, Canada, Ireland, New Zealand, the 
United Kingdom and the United States. CMEs are countries where firms depend more heavily on non-market relations to coordinate with other actors. They include Austria, Belgium, Denmark, Finland, Germany, Japan, Netherlands, Norway, Sweden and Switzerland (Hall and Soskice, 2001). In Hall and Soskice (2001), France and Italy are "in more ambiguous positions" and are hence categorized as mixed economies (or MIX).

Note 5. One such trade-off comes in the form of "flexicurity", a term used to describe the deregulation of certain protections for insiders while increasing benefits and ALMPs for outsiders. See for example Rhodes (2001) and OECD (2004). While this paper does not rule out the existence of these pacts, the analysis presented here indicates that they were not large enough in scope or common enough in frequency to affect the finding that strict employment protection and unemployment benefits have tended to go hand in hand in CMEs.

Note 6 . The tax wedge is the deviation from the price and quantity of a good supplied in equilibrium as a result of taxation, which results in labour becoming more expensive for employers and products more expensive for consumers.

Note 7. Job search assistance and related programs, however, generally have positive impacts in the short run. See Card, Kluve, \& Weber (2010) for a survey of active labour market policy evaluations.

Note 8. See, however, Huber and Stephens (2001), who find modest effects of partisanship on unemployment replacement rates in the period of welfare state construction.

Note 9. OECD governments have adjusted their spending on labour market programs since 1985 as a result of both changing labour market conditions and changing policy choices. See OECD (2009).

Note 10. The model also includes an intercept for each equation and an overall intercept, although these intercepts are not reported. See http://www.stata.com/meeting/chicago11/materials/chi11_drukker_sem.pdf for a complete description of this model.

Note 11. A quick graphical analysis revealed that all variables are approximately normal in their distribution.

Note 12. I thank Kristin MacDonald from Stata Corporation for clarifying this point to me.

Note 13. These models are sometimes referred to as one-way seemingly unrelated regressions (SUR) with panel data. See for example http://homepage.univie.ac.at/robert.kunst/pan2010_pres_gruber.pdf.

Note 14. Countries with proportional representation (PR) electoral systems, for example, tend to be corporatist and invest in specific skills whereas countries with single member majoritarian electoral systems tend to be pluralist and rely on a workforce in possession of general skills.

Note 15. http://stats.oecd.org/index.aspx?r=567112.

Note 16 . Venn reports a high and statistically significant positive correlation between the country rankings derived from the OECD indicators and from alternative measures of employment protection. Differences mainly reflect the range of aspects of employment protection covered by the various proxies. See Venn (2009).

Note 17. The OECD Benefits and Wages database provides a summary measure of benefit entitlements that combines replacement rates and the duration of benefits as a percentage of previous gross earnings. See http://www.oecd.org/document/3/0,3343,en_2649_34637_39617987_1_1_1_1,00.html. These measures, however, are pre-tax, pre-transfer; that is, they are calculated without subtracting taxes. The OECD database also provides post-tax or net replacement rates for three bouts of unemployment: long-term unemployment, an initial period of unemployment, and a five year period. Unfortunately, this data is only available from 2001 to 2007, a time when data for most covariates does not exist. Finally, Scruggs (2006) has released data on net replacement rates and duration of benefits for 18 OECD countries, but it is not possible to calculate the replacement rate for bouts of long duration from the data.

Note 18. Spending on unemployment compensation ranges from 0 to approximately 5 percent of GDP, whereas spending on ALMPs ranges from 0 to approximately 3 percent of GDP.

Note 19. See Huber and Stephens (2001) for a detailed description of this index.

Note 20 . With respect to the chief executive, for example, parliamentary government, which is a collective veto point, gets assigned a score of 0 , whereas presidentialism, which is a competitive veto point, is assigned a score of 1 .

Note 21. A more direct measure of the number and ideological distance among veto players is provided by Ha (2008) for OECD countries (see http://wfs.cgu.edu/hae/Research.html). This data, however, does not exist past the year 2000. In addition, it is arguably better to use measures of cabinet composition, government type, and constitutional veto players given the importance scholars of comparative political economy have attributed to the 
partisan composition of governments.

Note 22. There are only two observations for the last category, caretaker governments. This category is also not as important theoretically as the other five. I thus omit it from the presentation of the results.

Note 23. As further confirmation of this result, I estimated three separate models of the determinants of each program using OLS with panel corrected standard errors. The results (not shown) confirmed the finding that veto players are associated with more spending on unemployment compensation. They also confirm the association between EPL and more spending on compensation and ALMPs. Since these models do not account for dependencies among the different programs, they yield of course some differences with the models based on structural equation modeling. Most findings, however, are confirmed, particularly the more unexpected ones.

Note 24. The ratio of the between-to-within standard deviations is 7.42 . 